\title{
Competitive Advantage of Intrapreneurs in Start-Up Business: A Dynamic Model
}

\author{
Huijian Dong, Ph.D., CFA a* \\ a Assistant Professor of Finance at College of Business, Pacific University, Forest Grove, OR 97116, USA. \\ *Corresponding author's email address: hdong@pacificu.edu.
}

\section{A R T I C L E I N F O}

Received: 11-03-2016

Accepted: 07-04-2016

Available online: 19-05-2016

\section{Keywords:}

Dynamic model, entrepreneurs; innovation, intrapreneurs, start-up.

JEL Classification: M10, M13

(C) 2016 The Authors. This is an open access article under the terms of the Creative Commons Attribution License 4.0, which allows use, distribution and reproduction in any medium, provided the original work is properly cited.

\begin{abstract}
A B S T R A C T
Intrapreneurs, defined as the active and creative force in the entrepreneurs, starts new business as projects, groups, or departments within an existing firm. They represent the frontier of innovation in a current standing firm and explore new growth points for the hosting organization. On the other side, entrepreneurs that start new business compete with intrapreneurs in the same pool of potential clients in the broad market. This paper attempts to explore the competitive advantages of intrapreneurs relative to entrepreneurs when starting a new area of business. The paper employs a dynamic model to identify the necessary conditions that intrapreneurs ought to be endowed to dominate entrepreneurs. This study also identifies the conditions of providing innovation-friendly environment for intrapreneurs to dominate entrepreneurs.
\end{abstract}

DOI: http://dx.doi.org/10.18533/job.v1i4.24

ISSN: 2380-4041 (Print), 2380-405X (Online)

\subsection{Introduction}

In his widely-used Entrepreneurial Finance textbook, Steven Rogers from Harvard Business School for the first time defines intrapreneurs as the set of caretakers, developers, and innovators. This paper explores the competition between the two parties: intrapreneurs and new business start-up entrepreneurs. Specifically, this paper sets up a dynamic model to derive the necessary conditions that with-in firm new business dominates business in new start-ups. While existing brands and shared recourses can be the most common ideas that come into the audiences' minds about the relative benefits of with-in firm new business, their real benefits, yet can also be disadvantages, come from the greater liquidity pool provided by the hosting company.

One type of intrapreneurs work for the existing company and work on existing products to explore new group of clients by expanding the service spectrum and product diversity. The other type of intrapreneurs work for the existing company and work on developing new products and services in an area of market which the firm is less familiar with. An example of the former type is a personal computer manufacture company develops new twoin-one style tablet computers; and example of the latter type is a personal computer manufacture company starts to pursue the digital camera market which the company has less experience with. This paper focuses on the latter type, which is comparable to a new start-up business. In this study, I use intrapreneurs start-up to refer to the latter-type, which is to initiate new business within an existing firm; and use entrepreneurs start-up to refer to new business by starting up a company that is not existing at its current stage.

- This research is funded by Pacific University Faculty Development Grant. I appreciate the valuable comments made by the anonymous referees. 
Previous studies (Stowe and Gagne, 2015) specified many methods to measure, plan, and budget new start-up business with a new firm and new start-up business with an existing firm. The most widely-used methods are net present value (NPV), internal rate of return (IRR), payback period (PP), discounted payback period (DPP), and profit index (PI). However, such traditional methods only budgets new business rather than compare the performance amongst entrepreneurs. Fried and Tauer (2015) propose a index of entrepreneur performance that is scaled between zero and one, and the index can be used as a leading indicator of success. Backes-Gellner, Werner, and Mohnen (2015) further use a theoretical model to explore the joint effect of free-riding and peer pressure on effort in start-up teams. They find that increasing team size adversely affects the efforts of the individual team founders; and the peer pressure effect is stronger when team members have stronger social ties. Their study indirectly addresses that for an externally launched start-up firm, the efficiency of operation is stronger than the internally launched start-up firms. While this conclusion is confirmed by their paper using a data set from 214 start-up projects in Germany, the conclusion is lack of theoretical support.

On the other hand, Baptista, Karaoz, Mendonca (2014) explores the relationship of founders' backgrounds and new firm survival in the early years after startup. Their results are somewhat surprising as they find out that pre-entry capabilities significantly affects the early success of opportunity-based entrepreneurs, but have little to do with the early success of the ones who are passively involved in business start-ups. Such conclusion implies that externally initiated business might have a negative endowment compared to the internally initiated business.

Sahut and Peris-Ortiz (2014), however, draw different conclusion. Their results suggest that it is the small businesses, often externally established, provide a better conducive environment for entrepreneurship and innovation. Such environment is often not enriched by the know-how and resources characteristic of large-scale production. Such opposite conclusion between Baptista et al., (2014) and Sahut and Peris-Ortiz (2014) mainly origins from the different initiative of external business start-ups. Specifically, the willingness of starting a business versus the passive unemployment as the main reason of business establishment plays a vital role.

Stucki (2014) employs 10-year time series survey data for a group of Swiss start-ups and finds that financial constraints are persistent. In other words, this paper rejects the common intuition that financial constraints are only problems for the start-up companies in the first years. This conclusion supports the intrapreneurs as they have a stronger financial support from their existing employer. Yet Stucki (2014) does not focus on the degree of impact of such financial constraints and up until now, the question of balance point of advantages of intrapreneurs and advantages of entrepreneurs remains unsolved. This paper attempts to shed light on solving the equilibrium of this multi-constraints function.

\section{$2.0 \quad$ The model}

The model first assumes some preliminary common settings of intrapreneurs and entrepreneurs by comparing their major differences. Such difference is mainly from the ease of having access to resources, which is identified by the cost functions of resources. The resources can be categorized into three groups: human resources, financial resources, and intangible resources. The last group includes, but is not limited to, the availability of research and development outcomes, firm credits, goodwill, marketing network, and so on.

Suppose the human resources cost function is:

$$
\mathrm{L}=\mathrm{L}(s)
$$

The independent variable of the human resources cost function is the size of the company, and it is reasonable to assume that external start-ups, which are at the smaller-size phase, will incur higher human resource cost. Such higher cost is the compensation premium of job uncertainty due to the size. In other words,

$$
\frac{d L(s)}{d s}<0
$$

While the cost of human resources is largely determined by the industry in which the intrapreneurs and entrepreneurs operates, this paper implicitly assume that the intrapreneurs and entrepreneurs competing against each other are operating at the same industry. Therefore the cost function of human resources includes the industrial average compensation as an exogenous factor instead of an independent variable.

Assume the cost of financial constraint is also a function of firm's size. For intrapreneurs, the size of the existing firm is larger and the difficulty of financing per unit capital is lower as more collateral are available and more private and public equities are readily accessible. However, this is not the case for entrepreneurs. 
That said, the cost of financial constraint is not necessarily lower for intrapreneurs as they face the elder brother effect. This effect addresses the demand of capital from the existing employer of the intrapreneurs. The employer most often requests financial assistance from the intrapreneurs whose projects are gradually established to fund the newer develops of the firm, namely elder brother taking care of young brothers. Such request of assistance increases the cost of financial constraints of the intrapreneurs. This request also decreases the degree of financial freedom of the intrapreneurs, as they fail to independently make dividend and retained earnings decision as entrepreneurs can do. Yet on the other hand, intrapreneurs can make use of existing firm non-current assets such as PP\&E to save the business start-up cost. To sum up, the cost function of financial constraint is:

$$
\begin{aligned}
& \mathrm{K}=\mathrm{K}(s)+\mathrm{D}_{1} \mathrm{~F}-\mathrm{D}_{2} \mathrm{~N} \\
& \mathrm{D}_{1}=0 \text { and } \mathrm{D}_{2}=0 \text { for } s=S_{\mathrm{E}} ; \mathrm{D}_{1}=1 \text { and } \mathrm{D}_{2}=1 \text { for } s=S \mathrm{I}
\end{aligned}
$$

In function (2), $\mathrm{D}_{1}$ and $\mathrm{D}_{2}$ are dummy variables; $\mathrm{F}$ is the funding support the employer withdraws from the intrapreneurs to support the cash flow cycle of the firm. $\mathrm{N}$ is the non-current asset cost savings for intrapreneurs. Similarly,

$$
\frac{d K(s)}{d s}<0
$$

The cost of intangible resources is another consideration of the lump sum cost of initiating new business, both internally as intrapreneurs and externally as entrepreneurs. Such resource includes marketing network, brand recognition, R\&D sustainability, firm cash cycle credit, and so on. It is widely accepted that intrapreneurs gain a lower cost of the intangible resources because of the economies of scale and up-front preparation the employer of intrapreneurs provides. However, a major issue of such believe is the joint effect. When the credit and brand of the hosting employer turn into negative, such intangibles are no longer an asset but liabilities to the intrapreneurs. Entrepreneurs, on the other hand, do not have such heritage either as credit or burden at financial stress. To sum up, the cost function of intangible resource is:

$\mathrm{A}=\mathrm{A}(s)+\mathrm{D}_{3} \mathrm{~B}-\mathrm{D}_{4} \mathrm{C}$

$\mathrm{D}_{3}=0$ and $\mathrm{D}_{4}=0$ for $S=S_{\mathrm{E}} ; \mathrm{D}_{3}=1$ for $S=S_{\mathrm{I}}$ when the hosting firm is at financial stress; and $\mathrm{D}_{4}=1$ for $S=S_{\mathrm{I}}$ when the hosting firm is at positive cycle of ash flow and brand recognition.

This paper employs the most widely used Cobb-Douglas production function to indicate the productivity of the intrapreneurs and entrepreneurs. I further assume constant return to scale and same level of capital elasticity to production for both intrapreneurs and entrepreneurs.

Therefore the production function for both enterprises is:

$$
\mathrm{Y}=\mathrm{A} K^{\alpha} L^{1-\alpha}
$$

Or

$$
\mathrm{Y}=\left(\mathrm{A}(s)+D_{3} \mathrm{~B}-D_{4} \mathrm{C}\right)\left(\mathrm{K}(s)+D_{1} \mathrm{~F}-D_{2} \mathrm{~N}\right)^{\alpha} \mathrm{L}(s)^{1-\alpha}
$$

\subsection{The dynamic problem}

While the static comparison of the competitive advantage of the intrapreneurs relative to entrepreneurs is not applicable to the real business world, such comparison indicated in Equation (5) sets up the initial condition of the dynamic comparison.

$$
\left(\mathrm{A}\left(s_{I}\right)+\mathrm{B}-\mathrm{C}\right)\left(\mathrm{K}\left(s_{I}\right)+\mathrm{F}-\mathrm{N}\right)^{\alpha} \mathrm{L}\left(s_{I}\right)^{1-\alpha}>\left(\mathrm{A}\left(s_{E}\right)\right)\left(\mathrm{K}\left(s_{E}\right)\right)^{\alpha} \mathrm{L}\left(s_{E}\right)^{1-\alpha}
$$

In a dynamic setting, firms recursively increase the size of the firm by realizing profits in operations and reinvest such profit to decrease the cost of the financial constraints. The profit realized in dynamic setting is:

$P_{t}=\left(\mathrm{A}\left(s_{t}\right)+D_{3} B_{t}-D_{4} C_{t}\right)\left(\mathrm{K}\left(s_{t}\right)+D_{1} F_{t}-D_{2} N_{t}\right)^{\alpha} \mathrm{L}\left(s_{t}\right)^{1-\alpha}-\left(\mathrm{A}\left(s_{t}\right)+D_{3} B_{t}-D_{4} C_{t}+\mathrm{K}\left(s_{t}\right)+D_{1} F_{t}-D_{2} N_{t}+\mathrm{L}\left(s_{t}\right)\right)$

This profit is the determinant of the size of the firm at the next period in this infinitely-lived firm agent model:

$$
s_{t+1}=s_{t+1}\left(p_{t}\right)
$$

In fact, profit is not only endogenous to the firm size, but also it relieves the financial constraints of a firm by directly reducing the cost of obtaining capital at the next stage of production. Therefore $\mathrm{K}\left(s_{t+1}\right)=\mathrm{K}\left(s_{t}\right)-\left(\mathrm{A}\left(s_{t}\right)+D_{3} B_{t}-D_{4} C_{t}\right)\left(\mathrm{K}\left(s_{t}\right)+D_{1} F_{t}-D_{2} N_{t}\right)^{\alpha} \mathrm{L}\left(s_{t}\right)^{1-\alpha}+\mathrm{A}\left(s_{t}\right)+D_{3} B_{t}-D_{4} C_{t}+\mathrm{K}\left(s_{t}\right)+D_{1} F_{t}-$ $D_{2} N_{t}+\mathrm{L}\left(s_{t}\right)$

Similarly,

$$
\begin{aligned}
& A_{t+1}=\mathrm{A}\left(s_{t+1}\left(p_{t}\right)\right)+\mathrm{D}_{3} \mathrm{~B}-\mathrm{D}_{4} \mathrm{C} \\
& L_{t+1}=\mathrm{L}\left(s_{t+1}\left(p_{t}\right)\right)
\end{aligned}
$$


Formally, the firm's problem is:

s.t. (7), (8), and (9)

$$
\max _{A_{t,} K_{t}, L_{t}} p_{t+1}
$$

\subsection{Solving the model}

To use the model and the firm's problem to identify the competitive advantage of the intrapreneurs relative to entrepreneurs, I first identify the target function:

Or

$$
\left.p_{t+1}\right|_{s_{t}=s_{t, I}}>\left.p_{t+1}\right|_{s_{t}=s_{t}, E}
$$

$$
\begin{aligned}
& \left(\mathrm{A}\left(s_{t+1, I}\right)+D_{3} B_{t+1}-D_{4} C_{t+1}\right)\left(\mathrm{K}\left(s_{t+1, I}\right)+D_{1} F_{t+1}-D_{2} N_{t+1}\right)^{\alpha} \mathrm{L}\left(s_{t, I}\right)^{1-\alpha}-\left(\mathrm{A}\left(s_{t, I}\right)+D_{3} B_{t}-D_{4} C_{t}+\mathrm{K}\left(s_{t, I}\right)+\right. \\
& \left.D_{1} F_{t}-D_{2} N_{t}+\mathrm{L}\left(s_{t, I}\right)\right)>\left(\mathrm{A}\left(s_{t+1, E}\right)\right)\left(\mathrm{K}\left(s_{t+1, E}\right)\right)^{\alpha} \mathrm{L}\left(s_{t, E}\right)^{1-\alpha}-\left(\mathrm{A}\left(s_{t, E}\right)+\mathrm{K}\left(s_{t, E}\right)+\mathrm{L}\left(s_{t, E}\right)\right) \\
& \mathrm{Or}^{*} \\
& \ln \left(\mathrm{A}\left(s_{t+1, I}\right)+D_{3} B_{t+1}-D_{4} C_{t+1}\right)+\alpha \ln \left(\mathrm{K}\left(s_{t+1, I}\right)+D_{1} F_{t+1}-D_{2} N_{t+1}\right)+(1-\alpha) \ln \mathrm{L}\left(s_{t, I}\right)-\ln \mathrm{A}\left(s_{t, I}\right)-\ln \left(D_{3} B_{t}\right)+ \\
& \ln \left(D_{4} C_{t}\right)-\ln \mathrm{K}\left(s_{t, I}\right)-\ln D_{1} F_{t}+\ln D_{2} N_{t}-\ln \mathrm{L}\left(s_{t, I}\right)>\ln \left(\mathrm{A}\left(s_{t+1, E}\right)\right)+\alpha \ln \mathrm{K}\left(s_{t+1, E}\right)+(1-\alpha) \ln \mathrm{L}\left(s_{t, E}\right)- \\
& \ln \mathrm{A}\left(s_{t, E}\right)-\ln \mathrm{K}\left(s_{t, E}\right)-\ln \mathrm{L}\left(s_{t, E}\right)
\end{aligned}
$$

Through counter-recursively solving the problem we reach the initial condition of the setting, which is also the outcome that this paper pursues: under what condition the intrapreneurs have comparative advantage over entrepreneurs.

$$
\begin{aligned}
& \ln \left(\mathrm{A}\left(s_{1, I}\right)+D_{3} B_{1}-D_{4} C_{1}\right)+\alpha \ln \left(\mathrm{K}\left(s_{1, I}\right)+D_{1} F_{1}-D_{2} N_{1}\right)+(1-\alpha) \ln \mathrm{L}\left(s_{0, I}\right)-\ln \mathrm{A}\left(s_{0, I}\right)-\ln \left(D_{3} B_{0}\right)+\ln \left(D_{4} C_{0}\right)- \\
& \ln \mathrm{K}\left(s_{0, I}\right)-\ln D_{1} F_{0}+\ln D_{2} N_{0}-\ln \mathrm{L}\left(s_{0, I}\right)>\ln \left(\mathrm{A}\left(s_{1, E}\right)\right)+\alpha \ln \mathrm{K}\left(s_{1, E}\right)+(1-\alpha) \ln \mathrm{L}\left(s_{0, E}\right)-\ln \mathrm{A}\left(s_{0, E}\right)- \\
& \ln \mathrm{K}\left(s_{0, E}\right)-\ln \mathrm{L}\left(s_{0, E}\right)
\end{aligned}
$$

Initially the firms, under intrapreneurs or entrepreneurs, are assumed to have the same size, therefore the condition is updated to:

$$
\begin{aligned}
& \ln \left(\mathrm{A}\left(s_{1, I}\right)+D_{3} B_{1}-D_{4} C_{1}\right)+\alpha \ln \left(\mathrm{K}\left(s_{1, I}\right)+D_{1} F_{1}-D_{2} N_{1}\right)-\ln \left(D_{3} B_{0}\right)+\ln \left(D_{4} C_{0}\right)-\ln D_{1} F_{0}+ \\
& \ln D_{2} N_{0}>\ln \left(\mathrm{A}\left(s_{1, E}\right)\right)+\alpha \ln \mathrm{K}\left(s_{1, E}\right) \\
& \text { Or } \\
& \ln \left(\mathrm{A}\left(s_{1, I}\right)+D_{3} B_{1}-D_{4} C_{1}\right)+\alpha \ln \left(\mathrm{K}\left(s_{1, I}\right)+D_{1} F_{1}-D_{2} N_{1}\right)+\ln \left(D_{4} C_{0}\right)+\ln \left(D_{2} N_{0}\right) \quad>\quad \ln \left(\mathrm{A}\left(s_{1, E}\right)\right)+ \\
& \alpha \ln \mathrm{K}\left(s_{1, E}\right)+\ln \left(D_{3} B_{0}\right)+\ln \left(D_{1} F_{0}\right)
\end{aligned}
$$

At the beginning of intrapreneurs, assume the hosting company has no credit issue and the intangibles have positive cash flow impact, which are the fundamental conditions of initiating the business internally, then the conditions above can be further updated as:

$$
\ln \left(\mathrm{A}\left(s_{1, I}\right)-C_{1}\right)+\alpha \ln \left(\mathrm{K}\left(s_{1, I}\right)+F_{1}-N_{1}\right)+\ln \left(C_{0}\right)+\ln \left(N_{0}\right)>\ln \left(\mathrm{A}\left(s_{1, E}\right)\right)+\alpha \ln \mathrm{K}\left(s_{1, E}\right)+\ln \left(F_{0}\right)
$$

\subsection{Conclusion}

This paper explores the competition between the two parties: intrapreneurs and new business start-up entrepreneurs. Specifically, this paper sets up a dynamic model to derive the necessary conditions that with-in firm new business dominates business in new start-ups. The condition is solved and demonstrated in Equation (10).

Considering the economies of scale from the human resources, financing constraints, and intangible assets, the intrapreneurs have comparative advantages over entrepreneurs; yet they have heavier burden compared to the entrepreneurs due to the elder brother effect and possible brand pull-back if the hosting firm moves into negative public recognition cycle.

\section{Reference}

Backes-Gellner U, Werner A, Mohnen A. (April 2015) Effort Provision in Entrepreneurial Teams: Effects of Team Size, Free-Riding and Peer Pressure. Journal of Business Economics; 85(3):205-230. http://dx.doi.org/10.1007/s11573-014-0749-x

${ }^{*}$ This is due to $\mathrm{d}(\ln \mathrm{x}) / \mathrm{dx}>0$ and the monotonic increase function is reserved. 
Baptista R, Karaoz M, Mendonca J. (April 2014) The Impact of Human Capital on the Early Success of Necessity versus Opportunity-Based Entrepreneurs. Small Business Economics; 42(4):831-847. http://dx.doi.org/10.1007/s11187-013-9502-z

Fried H, Tauer L. (August 2015) An Entrepreneur Performance Index. Journal Of Productivity Analysis;44(1):6977. http://dx.doi.org/10.1007/s11123-015-0436-0

Sahut J, Peris-Ortiz M. (April 2014) Small Business, Innovation, and Entrepreneurship. Small Business Economics; 42(4):663-668. http://dx.doi.org/10.1007/s11187-013-9521-9

Stowe, J., and Gagne, J., (2015) Chartered Financial Analyst Program Curriculum, Vol. 4, pp. 10-20

Stucki T. (February 2014) Success of Start-Up Firms: The Role of Financial Constraints. Industrial And Corporate Change; 23(1):25-64. http://dx.doi.org/10.1093/icc/dtt008 